\title{
The Cost of Convenience
}

\author{
Lori Edwards
}

\begin{abstract}
When state legislatures mandate voting by mail and early voting in addition to Election Day voting, the cost of conducting an election disproportionately increases. Factors contributing to the cost of convenience include staffing, electronics, logistics, and materials. Since any voter may choose to vote by any mode at any time, duplicate preparation is needed to accommodate peak demand at all early voting sites, precincts, and Vote-by-Mail departments. Lawmakers often don't have the financial data they need to consider when making election administration policy, and although there is immense cost involved, data suggests that more opportunities to vote do not increase voter participation.
\end{abstract}

Keywords Mail voting • Early voting • Election convenience

- Election costs $\bullet$ Election policy

I am the Supervisor of Elections in Polk County, Florida, and have served since 2001. Polk County is located in central Florida along the Interstate 4 corridor between Tampa and Orlando and has a diverse population of about 680,000 people. In addition to conducting elections, our office is

L. Edwards $(\bowtie)$

Polk County Supervisor of Elections, Bartow, FL, USA

e-mail: loriedwards@polkelections.com

(C) The Author(s) 2019

M. Brown et al. (eds.), The Future of Election Administration, Elections, Voting, Technology, https://doi.org/10.1007/978-3-030-18541-1_11 
responsible for all voter registration activities, as well as candidate services. As an election official, of course my job is to conduct fair and accurate elections. Taxpayers expect this to be done efficiently. As new laws have been implemented, I think fairness and accuracy have increased. But policies designed to offer voter convenience have ballooned the cost of elections in obvious and many hidden ways. I'm not referring to the natural inflation that would occur as the price of goods and labor increase with time. This is the result of the cost of expanding the opportunity to vote.

\section{LEGAL LANDSCAPE}

To put the spotlight on Florida, all precincts are open from 7:00 a.m. to 7:00 p.m. on Election Day. Local supervisors of elections determine the number of precincts and their geographical configuration in consultation with their local board of county commissioners. Factors contributing to the size and boundaries of precincts include a unique combination of districts, communities of interest, traffic patterns, and suitable polling places. In some areas, the local governing body relies entirely on the Supervisor of Elections recommendations. In other areas, county commissioners prefer to be more involved in the mapping of precincts.

For a long time, poll lists, which contain the names of all eligible voters, were in a paper format at most Florida precincts. This changed following the passage of a law in 2013 that incentivized Supervisors of Elections to use electronic pollbooks (EPBs), which contain the voter registration file in electronic format. Now, if EPBs are deployed, voters moving from county to county may vote a regular ballot instead of a provisional ballot. This is much quicker for the voter and easier for poll workers and saves election officials hundreds of hours of research and processing provisional ballots immediately following the election.

Florida law allows "no excuse" voting by mail. Voters may request a ballot for a specific election any time up until 10 days before Election Day, or have a standing request for all elections through two general election cycles with no requirement to provide a reason such as illness or being out of town on the day of the election. Early voting, which occurs up to two weeks before Election Day, is also mandatory for all jurisdictions. The law requires at least the same number of early voting centers as the jurisdiction had in 2012. Early voting sites must be open 8-12 hours a day for at least 8 days but no more than 14 days. The law prescribes exactly which buildings may be used to provide early voting, including 
public libraries, fairgrounds, courthouses, stadiums, and convention centers. Public schools, private community clubhouses, or houses of worship are not allowed.

\section{Diminishing Returns}

Although there are more options for voting in Florida, we have not seen an increase in voter participation. A comparison of Florida turnout for presidential elections shows no growth or spike to accompany the provision of additional modes for voting (Fig. 11.1). When expenses increase while participation remains static, the law of diminishing returns is at play. The return on investment is decreasing as we strive to be more and more accommodating to voters.

To examine this a little closer, here are some examples from Polk County, a jurisdiction with 407,647 registered voters in the 2016 presidential election. Polk has held steady at 167 precincts for a dozen years, despite a $20 \%$ growth in population. There are nine early voting sites in Polk.

In the 1950s, fewer than $3 \%$ of Polk County's voters cast ballots by mail. These were probably our military and overseas voters. The rest voted

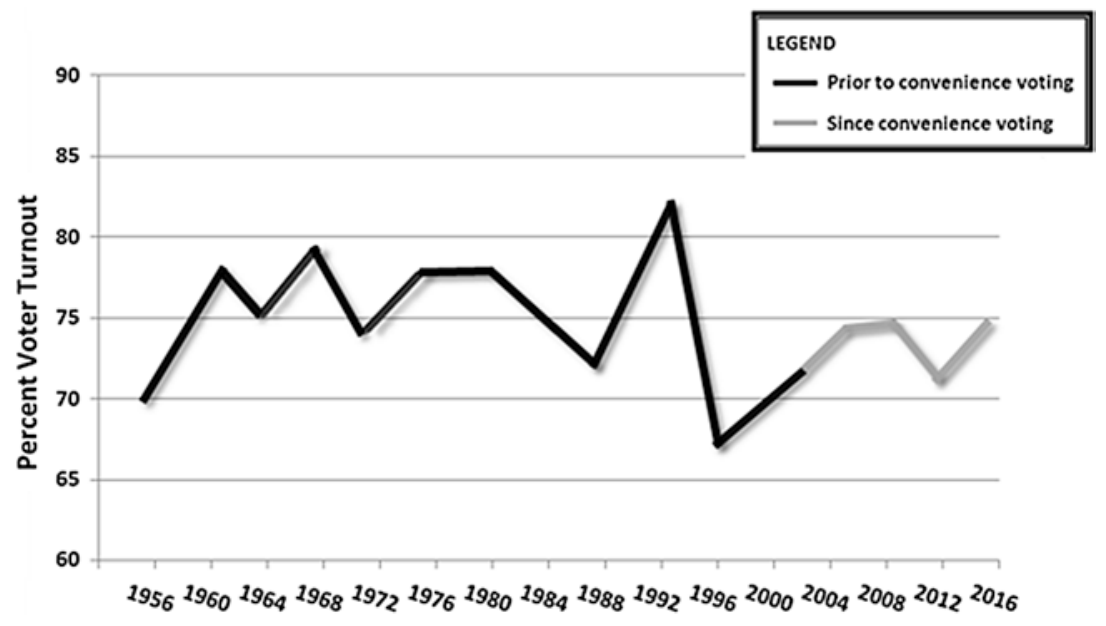

Fig. 11.1 Turnout in Florida 


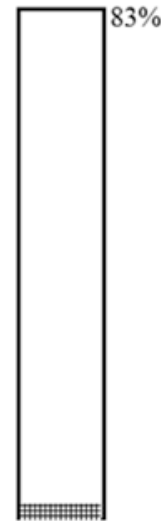

1952

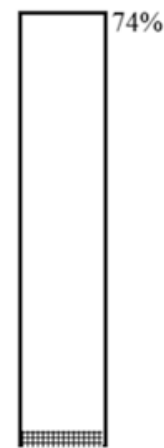

1956

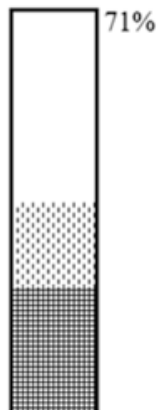

2012

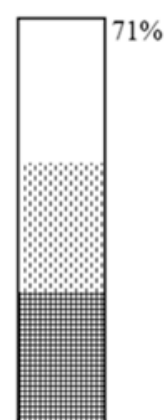

2016
Precinct

Early Voting

Mail Ballot 曲

Fig. 11.2 Changes in voting methods-Polk County

in person at their precinct on Election Day, as there were no provisions for early voting. Turnout in the 1952 presidential election was $83 \%$. In 1956, it was $74 \%$.

In 2012 and 2016, early voting and Vote-by-Mail were in full swing. Turnout in both elections was $71 \%$. In $2012,51 \%$ voted at the precinct on Election Day, $27 \%$ cast mail ballots, and $22 \%$ participated at an early voting center. In 2016, 40\% voted on Election Day, 28\% cast mail ballots, and $32 \%$ voted at an early voting site (Fig. 11.2).

As voters have changed their voting methods, we need more resources to accommodate these changes, and have to allocate resources differently.

\section{Contributing Factors}

\section{Move Polling Locations}

When Florida became a state in 1845 , voters residing within a defined area were to vote at a specific location, usually the county courthouse. Public officials or employees took time from their regular duties to facilitate the election and total the results. Cost to the government was negligible.

As the population grew and more people became eligible to vote, more precincts were created in Florida. Now there are more than 6000 precincts 


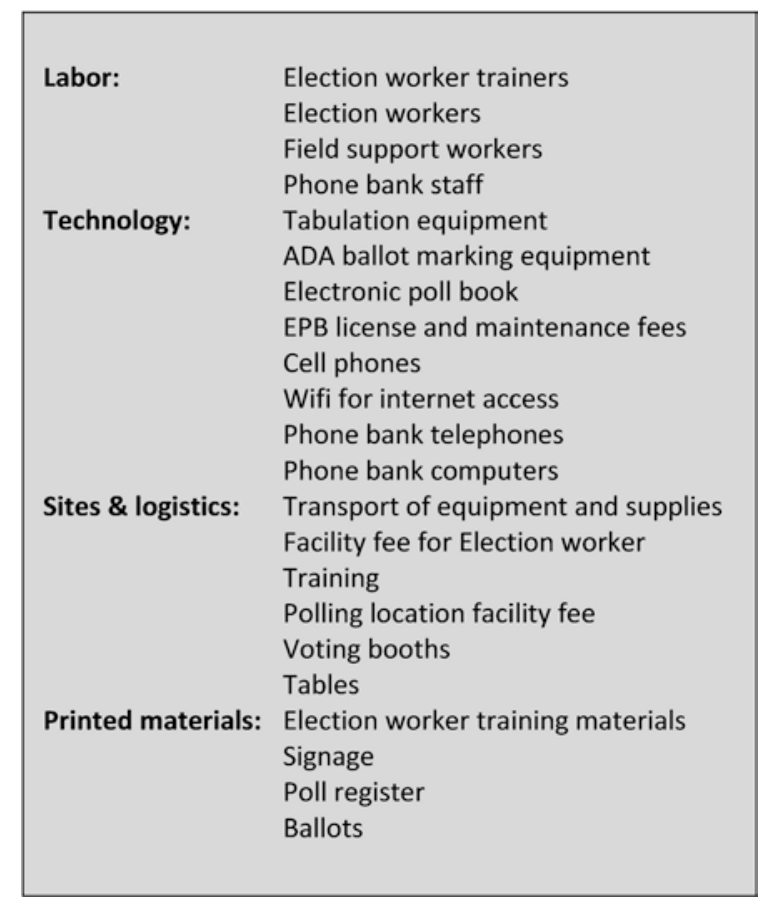

Fig. 11.3 Polling locations as a cost center

in the state, and voters expect to have a polling location that is convenient to their home and place of work. Polling locations are expensive and involve many costs that are not immediately apparent (Fig. 11.3). Voters expect polling locations to be in their neighborhood. Following the 2010 census and redistricting, a necessary shift in polling locations for some voters resulted in more than a few calls of complaint from voters who now had to travel an extra mile to vote at their precinct.

\section{Vote-by-Mail}

Vote-by-Mail, when combined with precinct voting, still can be efficient in high turnout elections. Of course, there are costs associated with printing two envelopes, privacy sleeve, and instructions for each ballot packet, along with the postage which is paid by the county. Staff must be paid to 
issue each ballot and process each ballot for mailing. Then, staff must be paid to receive each ballot, verify the signature on the ballot, mark the voter as having voted, present the ballot in the envelope to the Canvass Board, open the ballot envelope, reconcile the number of ballots, process the ballot through the tabulation unit, and replicate any ballot that may be unreadable by the tabulation unit.

When a voter requests a ballot in advance and then votes and returns that ballot, there is no duplication of effort. Since we know in advance that the voter intends to vote by mail, we will not plan on his/her attendance at the polling location. We will not purchase a ballot for that voter for their polling location, and when we staff their polling location, we subtract the mail ballot voters from the likely number of expected voters.

The convenience of voting by mail causes hidden costs when the voter does not vote their ballot. If they simply don't vote, we have incurred the costs of printing the ballot and ballot materials, issuing the ballot and postage even though the voter did not have interest in or intent to vote. Another way that the Vote-by-Mail option can cause additional costs is if the voter requests a ballot, the election office prints, prepares, and mails the ballot and then the voter decides to vote at an early voting location or precinct instead. In this scenario, which occurs thousands of times in Polk County during each general election, the voter requires 2 ballots, mail ballot materials, precinct resources, and staff at the precinct and election headquarters to cancel the mail ballot before the precinct ballot is provided.

Because of the convenient opportunity to vote by mail or vote at the precinct, a method to prevent a voter from casting a ballot both ways (voter fraud) is necessary. The most simple and inexpensive way to accomplish this is with an election worker on a telephone at the polling location speaking with a worker at Election Headquarters. For busy elections, or in mid- to large-sized jurisdictions, an automated process is needed, usually in the form of electronic poll registers connected to the internet via some form of temporary internet access. When poll registers or temporary internet access devices are deployed at each polling location, specialized support staff is usually needed to guide workers through common problems or go to the site to address more puzzling malfunctions.

\section{Early Voting}

For early voting, each election office must open short-term temporary voting sites staffed and equipped to provide voting to any eligible voter in the jurisdiction for 8-12 hours a day for a week or two before an election. 
Early voting sites incur all of the costs associated with a precinct, plus overtime, and often printers and toner.

One of the biggest challenges, and inefficiencies, of early voting is the unpredictability. Any voter can show up at any time, at any location. So, each location must have every possible ballot style available. All Florida counties use either the "pick and pull" method or ballot-on-demand to issue the correct ballot style to each voter. With the "pick and pull" method, each early voting site is stocked with an inventory of all ballot styles and the election worker selects a ballot from that stock for each voter. When ballot-on-demand is utilized, printers are deployed at each voting site and a ballot is printed for a voter once they check in and verify eligibility.

In Polk County, in a statewide primary election, there are at least 501 distinct ballot styles. The "pick and pull" method, which consists of each early voting site keeping an inventory on hand of each ballot style, would mean that each of the nine sites would need a supply of each style of printed ballot as well as suitable storage. Just 100 ballots of each style at each location would mean a ballot order of 450,900 ballots just for early voting, which is more than the total number of voters registered in the county.

The alternative-ballot-on-demand-means the purchase, maintenance, and storage of at least 40 laser printers and multiple toner cartridges for each, as well as the blank ballot stock.

\section{More Resources Than Voters}

It's the unpredictability that drives the cost. Election officials must prepare for more than $100 \%$ turnout. Below the story is told with ballots, because they are easy to count, but the cost of technology, logistics, supplies, and staffing grow at a similar pace.

In Polk County in 2016 there were 97,148 mail ballots sent per voters' requests. Of course, we needed to keep on hand at least 50 of each of the 167 ballot styles in a general election for last-minute ballot replacements or walk-ins. That's another 8350 ballots.

About six weeks before Election Day, ballots must be ordered from the printer for polling locations. At that point, new voters are still registering, so there's a moving target for the number of registered voters. Most officials would agree to expect turnout of $70 \%-85 \%$ for a presidential election. In Polk, we have precincts that turned out more than $90 \%$ of their voters. 


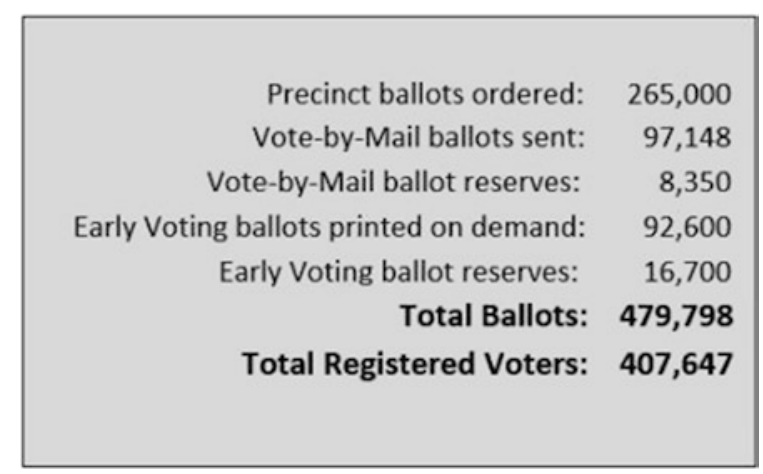

Fig. 11.4 Comparison of ballots to voters in 2016

It would be safe to order ballots for $65 \%$ of our voters to vote at the polls for a total of 265,000 ballots.

Early voting ballots are often print-on-demand, which eliminates the cost of commercial printing, but the expense of laser printers, toner, and paper stock are incurred. In 2016, 92,600 ballots were printed and voted at early voting sites. Also, any prudent election official would have a small quantity of emergency ballot supply for continuity of operations in case of a site evacuation or power failure. One hundred ballots of each style equates to 16,700 ballots (Fig. 11.4).

\section{Inconvenience as a Reason Not to Vote}

According to a Pew Research Center analysis of new Census Bureau data, registered voters who did not vote cited nine reasons more frequently than inconvenience. One quarter of the respondents said they didn't like the candidates or issues, $15 \%$ said they weren't interested, or thought their vote wouldn't make a difference, $14 \%$ were too busy. Just $2 \%$ of registered voters who did not vote cited inconvenient hours or polling locations. Increased convenience does not result in greater participation, and those who do not vote rarely claim inconvenience is their reason for not participating. 


\section{Challenges}

Policy decisions to increase convenience are often made by lawmakers who may not be aware of the relative financial impacts of the decisions they are making. And, while efficiency is a laudable goal for all government functions, it's not a primary objective when conducting an election. Even if they want to cut some financial corners, policymakers usually don't have the data they need. The study of the cost of elections is still in its infancy. Election administrators have struggled with the complexities of financial data collection in an environment of over 7000 jurisdictions ranging from hundreds to millions of voters operating under different laws in each state. The information in this case provides an in-depth look at one county in one state. Each of these in-depth looks help shape our understanding of costs, which will in turn shape a more complete picture of the particular cost data that matter, regardless of the differences across states. This understanding is particularly important given the popularity of the implementation of multiple options to enhance voter convenience.

Open Access This chapter is licensed under the terms of the Creative Commons Attribution 4.0 International License (http://creativecommons.org/licenses/ by $/ 4.0 /)$, which permits use, sharing, adaptation, distribution and reproduction in any medium or format, as long as you give appropriate credit to the original author(s) and the source, provide a link to the Creative Commons licence and indicate if changes were made.

The images or other third party material in this chapter are included in the chapter's Creative Commons licence, unless indicated otherwise in a credit line to the material. If material is not included in the chapter's Creative Commons licence and your intended use is not permitted by statutory regulation or exceeds the permitted use, you will need to obtain permission directly from the copyright holder.

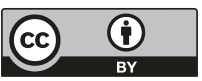

